\title{
Topical Issues Of State Educational Policy Of Russian Federation: Organizational And Legal, Didactic Aspects
}

\author{
Vorontsov A.L. \\ Department of Administrative and Labor Law \\ FSBEI HPE «South-West State University» \\ Kursk, Russia \\ vorontsov.a.1@mail.ru
}

\author{
Vorontsova E.V. \\ Department of Financial Law, Constitutional, Civil and \\ Administrative Proceedings \\ FSBEI HPE «South-West State University» \\ Kursk, Russia \\ proskyrinae@mail.ru
}

\begin{abstract}
The purpose of the study is to analyze the topical issues of the state educational policy related to the reform of the Russian education system and to formulate conclusions that justify the necessity of new model creation of this system development. The methodology of the whole study was based on the analysis technique. In this case, the study of certain aspects of the topic in question required the use of comparison methods, a method of formal logic, statistical and systemfunctional methods. The principle of dialectical unity of the processes and phenomena studied has acted as a basic principle of the research work of the authors. After analyzing the results of the first and second waves of educational reforms, the authors state the incompleteness of the processes of modernization of Russian education, which in their opinion was the result of strategic mistakes made both at the planning stage of educational reforms and during their implementation. Insufficient definition of reform goals, the wrong choice of final landmarks and schematism of ways to achieve them, the lack of a proper assessment of the social, material and technical conditions in which these changes were implemented, the introduction of foreign innovations without regard for national traditions in the field of education, all this could not but affect the results of reforms that are now far from ideal. The subject of the author's study was the basic didactic, organizational and legal problems of Russian education, especially in the field of higher education. Their analysis allowed the authors to draw conclusions and formulate proposals that can be used by the Russian legislator, the leadership of the Russian education, the scientific and educational communities of Russia and other countries in the course of developing recommendations for improving the educational policy and in the process of adopting normative acts in this field. Special attention is paid to the issues of re-profiling the system and the structure of vocational education in the Russian Federation and the implementation of a competence approach in the higher education system.
\end{abstract}

Keywords-Russian education, educational policy, higher education, educational reforms, vocational education, competences, modernization.

\section{INTRODUCTION}

Education has always been one of the determinants of social development since it allowed the positive sides of the national mentality to be used with the greatest degree of efficiency. At the same time, it is obvious that modern education in its essence has more "global" rather than "fragmentary" orientation, resulting from the supranational nature of knowledge, its general humanitarian orientation [1]. In the age of high technology, when a huge increase in the volume and importance of information is coming to the person, the role of education increases even more. This is explained not only by the complication of the production process and other social processes that require increasing the number of necessary human skills. The role of education as a system shaping the worldview is growing substantially; its importance can hardly be overestimated in the conditions of the globalizing world and the struggle of ideologies.

Profound changes in ideology and social order of the Russian society, taking place at the turn of the 90s of the XX century, could not but affect the sphere of education. The Russian Federation has made repeated attempts to reform this system, trying to adapt it to the changed social and economic conditions, but even now, there are a number of unresolved problems before the Russian education. A lot of these problems were the result of the ill-conceived educational policy of the state, its desire in a short time to rebuild such huge and inert system, leading it to the best world models.

The article analyzed the results of two waves of educational reforms that took place in Russia in the 1990s and 2000s. Based on the results of this analysis, one cannot fail to note the contradictory nature of the educational reform, the existence of multi-vector trends in the development of Russian education, which indicates the absence of a clear concept of educational policy in Russia.

A lot of members of the scientific and educational community in Russia do not understand the ultimate goals 
of the numerous state programs for the development of the educational sphere, which are not very specific in nature and often contradict each other. The mechanism of their achievement is not fully understood either, since the regulatory and legal framework of the educational sphere is subject to constant change in attempts to solve immediate problems. "Thus, there is an alienation of the university professional community from the ongoing transformations of the higher school, its distrust towards the designer of reforms" [2].

Thus, the current educational policy is not able to solve the problems of the national education system and modernize it in accordance with the requirements of the time. As before, the Russian education system is characterized by a whole range of organizational, legal and didactic problems, some of which the authors will consider in this article.

\section{THE EDUCATIONAL POLICY OF THE RUSSIAN FEDERATION IN THE PERIOD OF LIBERAL-DEMOCRATIC REFORMS}

Turning the page of its Soviet history, Russia was faced not only with the necessity of qualitative changes in the economy and the political system, but also with the necessity of a qualitative change in its «human potential», which, as it is known, underlies the development of any society. The transfer of the production sector in the mode of operation based on free market principles, the development of economic and cultural ties with the rest of the world and associated with this the transfer of the technology and workforce demanded changes throughout the professional training system. A new democratic Russia needed a large number of people with new knowledge, skills and abilities capable of acting under changed economic, social and information conditions. This circumstance objectively entailed a whole chain of reforms in the education system: from primary education to higher education. One should not forget the main element of the human potential of any nation - the worldview. In this connection, since the beginning of all democratic transformations, education has been given the important role of «redeveloping» the old soviet society, changing its outlook in the spirit of perceiving new universal human values of the free world [3].

The educational policy of the Russian Federation in the 1990 s of the XX century suggested a radical restructuring of the entire education system. First of all, the whole educational process was de-ideologized. This was done at all levels of education: at the level of basic general education; Secondary (complete) general education; Primary vocational education; Secondary vocational education; Higher professional education; Post-graduate professional education.

Marxism-Leninism ceased to be the dominant ideology (in fact, it turned out to be banned - so strong at that time was its rejection of society). Children's and youth organizations of October Children, Pioneers and Komsomol members were liquidated in schools. They were considered politicized, but in fact, the October Children and Pioneer organizations were only a Soviet counterpart to the Boy Scout movement in the West. The institutes, universities, academies and other institutions of vocational education, removed from their curricula such academic disciplines as Marxist-Leninist philosophy, scientific communism, the history of the Communist Party of the Soviet Union, and some others that were considered instruments of ideological influence. It is noteworthy that these transformations began to be implemented even before the adoption of the Constitution of the Russian Federation in 1993, where the provisions on the recognition of ideological diversity were enshrined in Article 13, and the idea was enshrined that no ideology can be established as a state or mandatory [4].

The consolidation of ideological diversity at the constitutional level entailed significant changes in the didactics of Russian education. Instead of an officially approved single textbook on this or that discipline in Russian schools and universities, a lot of textbooks appeared, but they did not go through state expertise and often had fundamental differences in their content. Foreign organizations and funds were attracted to the process of updating the content of educational programs and courses; they have been finance the implementation of these projects. As an example, let us mention the George Soros Foundation, which financed the program «Renewal of Humanitarian Education in Russia».

However, one must note that in the system of higher education, alternative textbooks were practiced since Soviet times, which, undoubtedly, had a positive significance, since it allowed one to become acquainted with various approaches in studying a particular science. But in the practice of school education, the use of fundamentally different textbooks and, accordingly, didactic schemes, arbitrarily determined by school management, often created difficulties for pupils at the stage of final exams, and with their transition from one school to another. In addition, many school textbooks on humanitarian disciplines had absolutely different ideological directions, which did not contribute to the formation of an integrated worldview of the younger generation.

As for higher education, the educational policy of Russia in the 90s in this sphere was aimed at its liberalization and increasing the accessibility of higher education for citizens. If in Soviet times, the citizen was limited in the choice of educational institution, and accordingly - to a certain extent limited in the choice of the future profession, then in the 90 s, the situation radically changed. The development of market relations in the economy as a whole and in education in particular led to the emergence of a large number of nongovernmental (private) universities. In addition, public universities were able to provide training on a fee basis. The Russian system of higher education, which in the Soviet era was exclusively public and ruled by the state, has evolved into a system with an indissoluble mix of private and public interests [5]. Both of these factors significantly increased the possibility of obtaining higher education for Russian citizens. There was a kind of "boom" of higher education in Russia. The annual number of citizens receiving a diploma of higher education increased in multiples. This was 
facilitated by the spread of the practice of obtaining higher education in a shortened time (for people who already have higher education or secondary specialized education).

Thus, the educational policy of the Russian state of the post-Soviet period made it possible in a short time to solve the problem of providing the new industries for the Russian economy with professional personnel, and the types of professional activity that are in demand in the new social and economic conditions. At the same time, the negative consequences of reforms were very soon manifested, among which the main was the decline in the quality of vocational training. This was a natural consequence of the general decline of the Russian economy (which did not allow students to obtain the necessary production practices at enterprises), and the uncontrolled development of the nonstate sector in the education system. In addition, low wages forced the most qualified scientific and pedagogical workers to change the scope of their professional activities, or to leave for work abroad.

\section{ORGANIZATIONAL, LEGAL AND DIDACTIC PROBLEMS OF RUSSIAN EDUCATION: THE NECESSITY OF FORMULATION A NEW STRATEGY FOR EDUCATIONAL POLICY}

The realities of the XXI century significantly increased the requirements for the level of training of graduates of educational institutions. In an effort to meet the standards of the new time, Russia has undertaken another major reform of the entire education system. At the heart of the educational policy of the 2000s, there was the common desire of Russia to integrate into the pan-European cultural and economic space. Many representatives of the Russian scientific and educational community sincerely believed that the main issue of reform is the creation of a single European intellectual space [6].. This caused active attempts to unify the national educational standards with the educational standards of the European countries that concluded the Bologna agreement. Russia joined this agreement in 2003, and it was from this time that the system and structural transformation of Russian education began towards its rapprochement with the educational systems of other countries.

The strategic mistake of the educational policy of this period was the conviction of the leaders of Russian education that the panacea in solving existing problems is the adoption of foreign experience. Hence, the main way to modernize the Russian education system was the mechanical reproduction of educational forms common in Europe. Moreover, copying of foreign standards was carried out without taking into account Russian national traditions in the sphere of education. The administrative-command method, characteristic of Russia for the management of the educational sphere, was added to this, which deprived the independent actions of many subjects of educational activity.

Reforming the education system was carried out on the basis of federal targeted development programs, such as Federal Targeted Program for the Development of Education for 2016-2020 [7], the Federal Target Program
«Research and Development in Priority Areas for the Development of the Scientific and Technological Complex of Russia for 2014-2020» (Decree of the Government of the Russian Federation №426, 2013), the Federal Target Program «Scientific and Scientific Pedagogical Staff of Innovative Russia for 2014 - 2020 years» [8], as well as orders and instructive letters of the Ministry of Education and Science. Moreover, the targeted development programs did not fully take into account the existing realities and the organizational, material and financial capabilities of the Russian Federation, which led to the need for adjustments and curtailment even before the planned deadlines for their implementation.

It should be noted that educational reform in Russia for a long time did not have the necessary legal support. Realization of the set goals within the framework of the outdated regulatory and legal framework led to unavoidable contradictions in the course of reforming actions. It was impossible to continue reforming the education system in this situation. In 2012, a comprehensive Federal Law "On Education in the Russian Federation" was adopted [9], which became the legal basis for the functioning of the entire system of Russian education. The adoption of this Law to some extent streamlined legal relations in the educational sphere, but did not completely eliminate the problems of educational reform.

The above-mentioned problems are primarily related to the content of the Federal Law itself. One of its innovations is the elimination of the level of primary vocational education. This is how the developers of the Federal Law "On Education in the Russian Federation" decided to modernize the system of training personnel in working specialties. According to this Law, most of the educational programs for primary vocational education have been transferred to vocational training programs, the acquisition of which is not accompanied by an increase in the level of education. At the same time, in the structure of secondary vocational education, which prepares middle-level specialists, there are programs for the training of skilled workers (employees). Thus, a person who has completed training under this training program acquires a level of secondary professional education, i.e. acquires the same level of education as a person who has completed training under the mid-level specialist-training program.

In the opinion of the authors of this article, the desire of the Russian state to raise the prestige of the working professions, and, consequently, to eliminate the shortage of workers in the workplace obvious in this case. At the same time, no one thought about how the mechanical unification of programs of different in essence and complexity within the same level of education will affect the prestige of the average vocational education.

The actual disparity of training programs for skilled workers (employees) and middle-level specialists is indirectly indicated in the provisions of the Federal Law "On Education in the Russian Federation". The Law says that the receipt of secondary vocational education in the programs of training a specialist of middle level by persons 
qualified as a skilled worker (employee) is not a secondary vocational education. For comparison, let us note that in the system of higher education the acquisition of a new specialty within the framework of one educational level is regarded as a re-acquisition of higher education.

The Federal Law "On Education in the Russian Federation" established in the system of higher education the transition to a two-level system of training professional personnel: bachelors and masters. At the same time, for a number of areas, the previously existing specialist level remained functional. At the same time, the previously existing specialist level for several areas remained functioning. It seems to us that such combination of modern foreign experience and educational standards of the Soviet era only confuses the situation, creating difficulties for the employer when hiring professional staff. Moreover, the preparation of bachelors and masters in Russian universities is not carried out according to European standards, compliance with which was one of the goals of educational reform. For example, when enrolling in a magistracy of a Russian university, the direction of the previous training of a person in a bachelor's degree is very often irrelevant. A person can apply for a master's degree in almost any direction. Of course, such practices adversely affect the quality of the education received (professional master's training). All this happens in the context of expanding the range of master's programs, which include many types of professional practice, which complicates the problem even more. This was pointed out by some Russian scientists [10]. In this connection, the order of admission to the magistracy, undoubtedly, requires its modification, in terms of establishing a clear correspondence between the previous training program of the person and the direction of preparation that he expects to receive in the magistracy. However, at present the educational law of the Russian Federation regulates this issue very generalized.

The situation is no better with the adaptation of foreign students to the educational environment of the Russian university and the promotion of the capabilities of Russian students for study abroad. Despite the fact that in Russia, a number of experts proposed models and methods of this adaptation, nevertheless they were not widely used in Russian educational practice [11].

There are no fewer problems with the implementation of the competence approach, which is the main one in vocational training in higher education. Despite the large number of normative documents of the Ministry of Education and Science devoted to this issue, the very content of the concept of "competence" is not quite clear so far. Of course, in the practice of educational activity, there is a certain generalized understanding of it [12], but there is no official definition of this term. At the same time, the federal state educational standards of higher education subdivide all the prospective competences into general cultural, general professional, special, etc. This is the general feature of the normative regulation of education in Russia, which consists in insufficient theoretical study and the "nebulosity" of the main provisions.
A feature of modern professional activity is the need for a comprehensive application of knowledge, and knowledge is not isolated, but representing a certain synthesis, this synthesized set of knowledge should be pre-configured for the possibility of applying it in different spheres of professional activity. This is the essence of the competence model for the training of professional cadres, now being implemented in Russia. However, in the Russian higher education there is still an obvious isolation and disunity of the academic disciplines (even within the framework of some training courses), which undoubtedly influences the professional outlook of the graduate of the university, significantly restricting it, and, accordingly, limiting the graduate's opportunities in further professional activities.

It seems to the authors of the article that it is possible to overcome this situation only through deep interdisciplinary integration. It is this approach that will make it possible to form a systemic set of competences, which is so necessary in today's labor activity.

The brief analysis of some organizational, legal and didactic problems of Russian education conducted by us testifies to the imperfection, the current educational policy and the need to formulate a new strategy for its development. The main provisions of this strategy will be stated by the authors in the conclusion of the proposed article.

\section{CONCLUSION}

The scope of this article does not allow us to present an expanded version of the new concept of the development of Russian education, which the authors propose. The authors will only point out the principal positions that, in their opinion, Russian lawmakers and the leadership of Russian education should adhere to in the implementation of educational reforms. These positions are reduced to the following:

1. Conjunctive political, financial, economic and other similar considerations cannot be the basis of the ideology of educational reform. Accordingly, any organizational, legal, technological, structural and didactic changes can be dictated solely by the interests of national development, namely the development of specific industries, the raising of the educational level of citizens, the development of the opportunity to acquire professional competencies. The main goal of any educational reform should be the interests of the development of the education system itself.

2. The very notion of "effectiveness of educational activities" existing in Russia requires its rethinking. It is necessary to change the criteria for evaluating the activities of educational institutions. The financial indicator cannot be determinative.

3. The development of a system of vocational schools (training highly skilled workers) requires stimulation at the state level.

4. Unification of the Russian education system with foreign systems cannot act as a self-sufficient goal of its reform. 
5. Without giving up the system of two-level training "Bachelor-Master", it is necessary to provide departmental educational institutions (financed from the resources of a specific ministry, department, business structure) with the opportunity to establish their own professional competencies within the educational levels that are stipulated in the Federal Law "On Education in the Russian Federation" .

\section{Acknowledgment}

We express our gratitude to the Institute of Philology and Intercultural Communication of Volgograd State University, the Department of Foreign Communication and Tomsk Polytechnic University for the opportunity to participate in the VII International Scientific and Practical Conference "Modern Problems of Linguistics and Linguodidactics: Interdisciplinary Approach in the Humanities", and appreciate the assistance of the organizers of the conference.

\section{References}

[1] N.A. Bondareva, "Integration as an innovative direction in education," Modern high technology, vol. 1, pp. 115-116, 2011.

[2] M. Kurbatova, "Higher Education Reform as an Institutional Project of the Russian Bureaucracy: the Content and the Outcomes," Mir Rossii, vol. 25, No 4, pp. 59-86, March 2016. (in Russian).

[3] A.L. Vorontsov, E.V. Vorontsova, "The necessity of forming a new educational paradigm in Russia: analysis of the current state of the national educational system," 3-rd International Multidisciplinary Scientific Conferences on Social Sciences and Arts, Book 1, Psychology and psychiatry, sociology and healthcare, education. Bulgaria: Albena, vol. 3. pp. 1169-1176, 2016.

[4] The Constitution of the Russian Federation (adopted by popular vote on 12.12.1993) (taking into account the amendments introduced by the Laws of the Russian Federation on Amendments to the Constitution of the Russian Federation No. 6-FKZ of December 30, 2008, No. 7-FKZ of December 30, 2008, -FKZ, from 11/21/2014 N
11-FKZ). Collection of the legislation of the Russian Federation. № 31. Art. 4398, April 2014.

[5] C. Sigman, "The transformations of Higher Education in Russia: The evolution of the public sector and its impact on universities' strategies," Revue d'Etudes Comparatives Est-Ouest, 45 (1), pp. 2154, 2014.

[6] I. Pryadko, I. Lebedev, "Problems of Russian construction education in an age of innovation: Socio-cultural and legal aspects," MATEC Web of Conferences, 106, State № 09015, 2017.

[7] Decree of the Government of the Russian Federation No. 497 of May 23, 2015 (as amended on 02.02.2017) "On the Federal Target Program for the Development of Education for 2016-2020". Collection of Legislation of the Russian Federation. № 22. Art. 3232, June 2015. Decree of the Government of the Russian Federation No. 426 of May 21, 2013 (Edited on December 26, 2016) "On the Federal Target Program" Research and Development in Priority Directions for the Development of the Scientific and Technological Complex of Russia for 2014-2020 ". Collection of Legislation of the Russian Federation. № 22. Art. 2810, March 2013.

[8] Decree of the Government of the Russian Federation No. 424 of May 21, 2013 (as amended on October 23, 2014) "On the Federal Target Program" Scientific and Scientific Pedagogical Staff of Innovative Russia "for 2014-2020 and the introduction of changes to the federal target program" Scientific and Scientific -pedagogical cadres of innovative Russia "for 2009 - 2013". Collection of Legislation of the Russian Federation, No. 22. Article 2808, June 2013.

[9] The Federal Law No. 273-FZ of December 29, 2012 (as amended on May 1, 2017) "On Education" // Rossiyskaya Gazeta. № 303. 31.12.2012.

[10] I.Y. Burkhanova, E.V. Bystritskaya, D.I. Voronin, R.U. Arifulina, S.I. Aksenov, "Expansion of professional pedagogical thinking of master's students in conditions of practice," Man in India, 97 (3), pp. 187-198, 2017.

[11] S.V. Barabanova, R.V. Shagieva, S.S. Gorokhova, O.V. Popova, A.A. Rozhnov, A.V Popova,. "Innovative components in the educational strategy of training the modern graduates," Mathematics Education, 11 (9), pp. 3329-3338, 2016.

[12] A.L., Vorontsov, E.V. Vorontsova, "Innovative Education in Russia: The Basic Tendencies Analysis," Procedia - Social and Behavioral Sciences, vol. 214, pp. 1147-1155, December 2015. 